\title{
Genetic diversity and virulence of Striga hermonthica from Kenya and Uganda on selected sorghum varieties
}

\author{
KATAKA ATANDA JOEL ${ }^{1}$, STEVEN RUNO ${ }^{1, \bullet}$, ALICE MUCHUGI ${ }^{2}$ \\ ${ }^{1}$ Department of Biochemistry and Biotechnology, Kenyatta University. P.O Box 43844, Nairobi, Kenya. `email: smruno@gmail.com, \\ runo.stephen@ku.ac.ke \\ ${ }^{2}$ International Centre for Research in Agroforestry. P.O Box 30677, 00100, Nairobi, Kenya
}

Manuscript received: 14 February 2018. Revision accepted: 30 May 2018.

\begin{abstract}
Joel KA, Runo S, Muchugi A. 2018. Genetic diversity and virulence study of Striga hermonthica from Kenya and Uganda on selected sorghum varieties. Nusantara Bioscience 10: 111-120. Parasitic weeds pose a severe problem in agricultural production, causing massive crop losses in many regions of the world and especially Africa. One example to be considered the most significant biological constraint to food production in sub-Saharan Africa (SSA) is Striga hermonthica, the most widespread among the Striga species in the semi-arid tropical African zones. The wide geographical distribution set conditions for genetically structured populations. The genetic variations among the weed populations allow for the quick breakdown of resistance in crops hence making control of the weed difficult. Efficient and effective control of $S$. hermonthica demands knowledge on inherent genetic variability within local and regional races of the weed. However, the genetic diversity and virulence of S. hermonthica ecotypes in Kenya and Uganda on selected sorghum varieties remain unknown. This study aimed at evaluating the genetic diversity among seven $S$. hermonthica populations from locations in Kenya and Uganda using 5 primer sets of Expressed Sequence Tags-Simple Sequence Repeats (EST-SSR). The genetic diversity was moderate as shown by the Nei's genetic distance values. AMOVA measured low genetic differentiation among the populations. This study also investigated twelve sorghum varieties for their response to $S$. hermonthica infection. The result demonstrated that the varieties resistance responses to $S$. hermonthica varied widely. The phenotype of resistant interaction was characterized by the inability of the weeds haustoria to penetrate the sorghums root endodermis due to severe necrosis and in rare cases the parasites radicle growing away from the host root. The resistant sorghum varieties were the Asareca W2, Asareca AG3, N13 and the Wild-type which had low mean number of $S$. hermonthica plantlets growing on their roots, while the most susceptible varieties were Sap 027, Epurpur which had the highest mean number of $S$. hermonthica plantlets growing on their roots. There was a highly significant difference in the means of the number of Striga growing on the roots of sorghum varieties, Striga dry biomass and S. hermonthica length between the susceptible and resistant ones. This knowledge holds unique potentiality since resistant sorghum germplasm tested will be sourced and targeted to the seven specific geographical areas where virulence of the particular $S$. hermonthica populations was characterized.
\end{abstract}

Keywords: Ecotypes, genetic diversity, Kenya, Striga hermonthica, Uganda, sorghum, virulence

\section{INTRODUCTION}

Striga weed is commonly known as witchweed and a noxious root hemi-parasite that has devastated cereal production in Sub-Saharan Africa (SSA) (Runo et al. 2012). The genus comprises of 30 to 35 species and now classified in the family of Orobanchaceae although earlier authors placed it in Scrophulariaceae family (Gethi et al. 2005). Over $80 \%$ of Striga species are found in Africa, while the rest occur in Asia (Westwood 2009).

The dominant agricultural Striga species are; $S$. hermonthica, S. asiatica, which infects cereals like maize (Zea mays), millet (Sorghum bicolor) and rice (Oryza sativa) and $S$. gesnerioides which infect Vatke legumes like cowpea (Vigna unguiculata). Other species such as $S$. forbesii and $S$. aspera have been reported to have sporadic effects on cereal crops in their locations (Parker 2009). Crops such as wheat (Ejeta 2007a) and Napier grass (Atera et al. 2012a) previously unaffected by Striga are now showing severe infection.

Depending on species, Striga parasites reproductive schemes vary from autogamy to obligate allogamy (Musselman 1987). S. hermonthica and S. aspera are the only two species known to be obligately allogamous and require insect pollinators. These two species can hybridize and produce viable and virulent offspring; a phenomenon that produces broader genetic variability within the species, creating even much more challenging to develop resistant crop varieties (Parker 2009).

Striga hermonthica is the most widely spread parasitic root weed among all species (Rasha et al. 2009). The geographical distribution, as well as the infestation level of the weed, are steadily increasing particularly in SubSaharan Africa (Emechebe 2004; Ejeta 2007a). This is favored by favorable climate, reduced soil fertility (Sauerborn et al. 2003), expansion of the area cropped with susceptible host crops, and increased land use on depleted soils (Gressel et al. 2004).

Striga parasite infests $40 \%$ of the cereal producing areas of SSA, resulting in crop losses estimated at US\$ 7 billion annually affecting the livelihood of about 300 million people (Ejeta 2007a). The most affected are 
subsistence farmers losing about $20 \%$ to $80 \%$ of their yield (Gethi et al. 2005). However, the percentage yield loss depends on many factors; Striga density, land use system, host species, soil nutrient status and rainfall patterns (Atera et al. 2012b). A survey done in Western Kenya in 2009 reported that $73 \%$ of the fields used for growing crops were infected with $S$. hermonthica (Woomer and Savala 2009); this is a fair indication that Striga is the most damaging pest experienced by farmers in those areas. Striga weeds, in essence, impairs the struggle to attain food security in Africa and consequently its control must be addressed by all efforts (Atera et al. 2012a).

Cultural management methods for Striga have not achieved much under its control (Atera et al. 2012b). Practices such as weeding, pulling and slashing are futile because the devastating effects of the parasite are accomplished before its emergence. Many research has been done to identify cultivars of several species that are resistant to Striga parasitization (Mohamed et al. 2003; Ejeta 2007b). The utilization of resistant varieties has however been ineffective by the high genetic diversity within the Striga species; the resistance is often weak and tends to break down with the infestation of new races of the Striga species (Rispail et al. 2007). The use of herbicides such as $2.4 \mathrm{D}$, Oxyfluorfeen, and Imazapyr is the available application for use. Nevertheless, it is a control measure that is unfortunately beyond the investment abilities of most small-scale farmers (AATF 2011). Therefore, it calls for an urgent need for the establishment of better policies to promote, implement and ensure long-term sustainable Striga control programs.

Recent molecular advance has provided the necessary tools that can be used in Striga diversity studies. Molecular markers are DNA sequences associated with certain parts of the genome and are presumed to be the most critical applications in the study of population genetic structures and genetic variability of crop pathogens (Koyama 2000). Examples of molecular markers include; Randomly Amplified Polymorphic DNA (RAPD), Restriction Fragment Length Polymorphism (RFLP), Amplified Fragment Length Polymorphism (AFLP), and Simple Sequence Repeats (SSR). These markers offer better characterization due to their high level of polymorphism as compared to the morphological markers.

Considering the full range of distribution of Striga species, few studies on the genetic diversity have been performed relative to their total current distribution (Runo et al. 2012). In general, there is lack of knowledge by farmers on the most resistant sorghum varieties which have contributed to low sorghum production. Screening of sorghum varieties to determine the most resistant ones is critical for farmers in Kenya and Uganda since the use of the resistant varieties is considered the most appropriate means of combating the weed.

The objectives of this research were (i) to determine if there exist genetic diversity and variations among the seven $S$. hermonthica populations infesting sorghum in Western Kenya and Eastern Uganda using EST-SSR, (ii) to screen selected sorghum varieties for their response to $S$. hermonthica infestation.

\section{MATERIALS AND METHODS}

\section{Genetic diversity of Striga hermonthica ecotypes Plant materials}

Striga hermonthica seeds were collected from sorghum fields from seven locations in Kenya and Uganda in 2013 (Table 1).

\section{Seed pre-conditioning and culturing}

The seeds of Striga spp. require preconditioning (or warm stratification) for a specified period at a suitable temperature before they can become responsive to germination stimulants (Matusova et al. 2004). Preconditioning was done under sterile conditions in a Laminar flow hood. Striga seeds $(20 \mathrm{mg})$ were sterilized in $10 \%(\mathrm{v} / \mathrm{v})$ sodium hypochlorite (commercial bleach) solution for 30 minutes in a test tube with mild agitation. The samples were then rinsed thoroughly with $200 \mathrm{ml}$ of sterile distilled water, spread on a glass fiber filter paper (Whatman GFA), then put into sterile Petri dishes and wet with $5 \mathrm{ml}$ of sterile distilled water. The Petri dishes were sealed with parafilm and wrapped with aluminum foil and placed in an incubator for 11 days at $29{ }^{0} \mathrm{C}$ for conditioning.

Following conditioning, the Striga seeds were treated with a sterile germination stimulant (GR 24) to induce germination. The stimulant (five milliliters) was added to each petridish having the pre-conditioned seeds. The seeds were then transferred into the growth chambers (14 hours) to allow for germination before being transferred to solid MS media (Murashige and Skoog 1962). Germination is completed when the radicle protruded through the seed coat.

The seed germination was confirmed by viewing under a stereo microscope. The glass fiber filter papers having the sprouted Striga seeds were removed from the Petri dishes and dried for 20 minutes in the laminar flow as the surplus moisture was removed through evaporation. After drying, the seeds were placed to another petridish containing solid MS growth media (Murashige and Skoog 1962) by detaching them off using a soft sterile paint brush. Incubation of the seeds was carried out in darkness at $29{ }^{\circ} \mathrm{C}$ for 21 days after which the Striga seedlings had enough tissue for DNA extraction.

Table 1. Locations where Striga seeds for the study were collected in Kenya and Uganda

\begin{tabular}{llll}
\hline Country & $\begin{array}{l}\text { Population } \\
\text { number }\end{array}$ & Region & Locality \\
\hline \multirow{2}{*}{ Kenya } & 1 & Malava & $0^{\circ} 26^{\prime} \mathrm{N}, 34^{\circ} 51^{\prime} \mathrm{E}$ \\
& 2 & Sio port & $0^{\circ} 13^{\prime} \mathrm{N}, 34^{\circ} 01^{\prime} \mathrm{E}$ \\
& 3 & Ndhiwa & $0^{\circ} 44^{\prime} \mathrm{S}, 34^{\circ} 21^{\prime} \mathrm{E}$ \\
& 4 & Kibos & $0^{\circ} 04^{\prime} \mathrm{S}, 34^{\circ} 49^{\prime} \mathrm{E}$ \\
Uganda & 5 & Mbale & $1^{\circ} 04^{\prime} \mathrm{N}, 34^{\circ} 10^{\prime} \mathrm{E}$ \\
& 6 & Bugiri & $0^{\circ} 34^{\prime} \mathrm{N}, 33^{\circ} 45^{\prime} \mathrm{E}$ \\
& 7 & Iganga & $0^{\circ} 39^{\prime} \mathrm{N}, 33^{\circ} 25^{\prime} \mathrm{E}$ \\
\hline
\end{tabular}


DNA extraction procedure

DNA was extracted from 30 randomly selected individual seedlings from each of the sampled populations using the CTAB method (Doyle and Doyle 1987).

\section{DNA estimation and quantification}

The quantity and quality of the Striga genomic DNA were estimated by running it on a $1 \%(\mathrm{w} / \mathrm{v})$ agarose gel. Two microliters of extracted genomic DNA was mixed with $5 \mu$ l of loading dye (New England Bio Labs Company) (NEB) and $1 \mu$ lof SYBR ${ }^{(\mathrm{R})}$ green (LTC). The DNA was electrophoresed alongside $5 \mu \mathrm{l}$ of $1 \mathrm{~kb}$ ladder (NEB). The electrophoresis was run at 100 volts for 30 minutes and then visualized using an ultraviolet transilluminator (Bio view) and documented using a digital camera. The concentration of the DNA was estimated by measuring the absorbance of a sample at $260 \mathrm{~nm}$ using Nanodrop spectrophotometer ND-100 (Thermo Fisher Scientific Inc.) with a dilution factor of 50. The purity of the DNA was determined using the 260/280 ratio. Only samples of high DNA quality were used for downstream analysis.

\section{Polymerase chain reaction (PCR)}

Primers consisting of five pairs of oligonucleotide labeled with fluorescent dye (Table 2) (Applied Biosystems $\mathrm{UK})$ were used to amplify SSRs in PCR reactions containing $5 \mu \mathrm{l}$ of $5 \mathrm{x}$ reaction Buffer with $5 \mathrm{mM}$ dNTPs, $15 \mathrm{Mm} \mathrm{MgCl}_{2}$, forward and reverse primer, $0.3 \mu \mathrm{l}$ of MyTag DNA polymerase and DNA template in a final volume of $25 \mu$ PCR reaction mixture.

The PCR amplification reactions were done in an Eppendorf master cycler. Parameters for a single thermocycler were initial denaturation at $94{ }^{\circ} \mathrm{C}$ for $3 \mathrm{~min}$, first cycle first step; $94{ }^{\circ} \mathrm{C}$ for 1 minutes, annealing $40{ }^{\circ} \mathrm{C}$ for 1 minute, extension $720 \mathrm{C}$ for $1 \mathrm{~min}$. The PCR was run at 40 cycles with a final elongation of $10 \mathrm{~min}$ at $720 \mathrm{C}$. The PCR product was stored at $-20^{\circ} \mathrm{C}$ until analyzed.

\section{Fragment analysis}

One microliter of each reaction of the PCR amplification was mixed with $9 \mu$ of HIDI formamide and Liz 500 size standard cocktail $(1: 12 \mathrm{v} / \mathrm{v})$. In a 96 well sequencer plate, the mixture was vortexed and denatured at $95{ }^{0} \mathrm{C}$ for 3 minutes and immediately quenched on ice for 5 minutes. Analysis of fragment was carried out by capillary electrophoresis (ABI $3730^{\circledR}$ Applied Biosystems). GeneMapper software version 4.0 (Applied Biosystems) was used for genotypes scoring.

\section{Data analyses}

Genetic diversity parameters were calculated using GenAIEx 6.1 (Peakall and Smouse 2012) and PowerMaker 3.0 (Liu and Muse 2006) software. The genetic distance matrix was generated according to Nei (1972), using the PowerMarker software. A Principal Component Analysis (PCA) was run based on genetic distance with data standardization in GenAIEx software to visualize differences between populations. As a supplement to the PCA analysis, a dendrogram was constructed using the unweighted pair group method (UPGMA) for estimating the genetic similarity based on Neiees genetic distance among the populations.

Comparisons of the pairwise population were analyzed with an Analysis of Molecular Variance (AMOVA) using GenAIEx 6.1 software based on 999 permutations. The AMOVA estimates and partitions total molecular variance within and between populations and then test the significance of partitioned variance components using permutational testing procedures. The AMOVA was also conducted to calculate the genetic differentiation between the populations $\left(\mathrm{F}_{\mathrm{ST}}\right)$ using stepwise mutation. The number of migrants per generation was measured from $\mathrm{F}_{\mathrm{ST}}$ value using the equation $\mathrm{Nm}=[(1-\mathrm{Fst})-1] / 4$ to determine the gene flow among the populations.

\section{Assessment of sorghum for their response to Striga hermonthica infection \\ Plant materials}

Sorghum seeds were collected from USA, Sudan, Eritrea, Kenya and Uganda (Table 3).

\section{Sorghum seed germination}

Sorghum seeds were germinated between blocks of moistened horticultural rockwool (Growdan ${ }^{\mathbb{B}}$ Vital Growdan, Roermond, Netherlands).Four days old sorghum seedlings were transferred to a root observation chamber (Rhizotron) as earlier discussed by Gurney et al. (2006). A single sorghum seedling was transferred to each rhizotron.

Table 2. Sequences of oligonucleotide fluorescent dye-labeled primers used to PCR amplify SSRs. The primers are given in their 5 ' to 3 ' orientation

\begin{tabular}{lll}
\hline & \multicolumn{2}{l}{ Primer sequence (5' to 3') } \\
\hline SSR 26 & Forward & CAACAAAACAATGCGTGGA \\
& Reverse & GGGTTGATCACTCTGTGCAGT \\
SSR 43 & Forward & CCACTGAAATCACAGGACGA \\
& Reverse & GTGACCGCCGTTACCATTAG \\
SSR 53 & Forward & GCAACTGAATGGAAGGAAGC \\
& Reverse & CTCGGCTGATCCATCTGTTT \\
SSR 58 & Forward & ACCGAGTGGTTCAAGATTGC \\
& Reverse & TGCTTCCAATACCGATCACA \\
SSR 63 & Forward & TTTTGTTGGGGTTTATGTGGA \\
& Reverse & TGGGAGAAAAATGGAATTAA \\
\hline
\end{tabular}

Table 3. The country of origin of the sorghum genotypes used in this project

\begin{tabular}{lll}
\hline Sorghum & Country & Locality \\
\hline SAP 027 & USA & $37^{\circ} 39^{\prime} \mathrm{N}, 88^{\circ} 19^{\prime} \mathrm{W}$ \\
SAP O34 & USA & $37^{\circ} 39^{\prime} \mathrm{N}, 88^{\circ} 19^{\prime} \mathrm{W}$ \\
SAP 048 & USA & $37^{\circ} 39^{\prime} \mathrm{N}, 88^{\circ} 19^{\prime} \mathrm{W}$ \\
N13 & Icrisat Kenya & $0^{\circ} 00^{\prime} \mathrm{S}, 37^{\circ} 53^{\prime} \mathrm{E}$ \\
SRS 208/1 & USA & $37^{\circ} 39^{\prime} \mathrm{N}, 88^{\circ} 19^{\prime} \mathrm{W}$ \\
Asareca AG3 & Sudan & $12^{\circ} 50^{\prime} \mathrm{N}, 30^{\circ} 20^{\prime} \mathrm{E}$ \\
Asareca W2 & Sudan & $12^{\circ} 50^{\prime} \mathrm{N}, 30^{\circ} 20^{\prime} \mathrm{E}$ \\
Epurpur & Uganda & $1^{\circ} 25^{\prime} \mathrm{N}, 30^{\circ} 20^{\prime} \mathrm{E}$ \\
Wild 1 & Sudan & $12^{\circ} 50^{\prime} \mathrm{N}, 30^{\circ} 20^{\prime} \mathrm{E}$ \\
Wild 2 & Sudan & $12^{\circ} 50^{\prime} \mathrm{N}, 30^{\circ} 20^{\prime} \mathrm{E}$ \\
Ochuti & Kenya & $0^{\circ} 00^{\prime} \mathrm{S}, 37^{\circ} 53^{\prime} \mathrm{E}$ \\
Sekedo & Uganda & $1^{\circ} 25 \mathrm{~N}, 30^{\circ} 20^{\prime} \mathrm{E}$ \\
\hline
\end{tabular}




\section{Striga seeds conditioning}

The same day sorghum seedlings were transferred to the rhizotrons to ensure that by the time the sorghum plant is ready for infection with the Striga seeds, they have already been conditioned. The germination of the Striga seeds was induced by adding $5 \mathrm{ml}$ of artificial germination stimulant GR24 $(0.1 \mathrm{ppm})$ in each petridish containing the seeds, 18 hours before infection (Gurney et al. 2006). Striga Seeds were triggered to germinate before being inoculated on sorghum roots to ensure their synchronous attachment to the roots thereby eliminating any differences that may occur as a result of variations in production of germination stimulant by different sorghum plants (Jamil et al. 2011).

Infection of sorghum seedlings with Striga hermonthica

Ten days after the transfer of sorghum plants to the rhizotrons, Sorghum roots were inoculated with pregerminated $S$. hermonthica seeds $(40 \mathrm{mg}$ ) from Malava population. The seeds were aligned along the host roots using a fine paint brush. The rhizotrons were covered with foil to prevent light from reaching the roots. Rhizotrons were fed with $25 \mathrm{ml}$ of $40 \%$ (v/v) Long Ashton nutrient solution (Hewitt 1966) twice a day. One plant was utilized for each treatment in three independent experiments.

Determination of attachment of Striga hermonthica radicle on roots of sorghum seedlings

Using a charge-coupled device camera (CCD) (Diagnostic Instruments Inc.) mounted on a Leica MZFL stereomicroscope (Leica Instruments $\mathrm{GmbH}$ ), pictures were taken 6 days after infection to determine if the Striga radicles had attached to the sorghum roots. It usually takes 4 to 7 days for attachment. Twenty-one days after infection of sorghum with the Striga, the root system of sorghum on each rhizotron was photographed using a Sony digital camera (Sony Corporation Minato-ku Tokyo, Japan) for quantification of post-attachment resistance.

\section{Phenotype of resistance}

Striga seedlings growing on the roots of each of the infected sorghum plants were harvested 21 days after infection. The harvested Striga plants from each host plant were photographed using Sony Cyber-shot (Sony Corporation Minato-ku Tokyo, Japan). The length and number of Striga plants on each host plant were calculated from the photographs using image analysis software (ImageJ, Media Cybernetics). Next, the Striga seedlings were dried at $48{ }^{\circ} \mathrm{C}$ in the oven for two days, and the weigh of dry mass per host plant determined.

\section{Statistical analysis}

Statistical analysis of variance (ANOVA) was performed using the version 3 of Statistical Package for the Social Sciences (SPSS) (IBM Corporation). Data for dry biomass, number of Striga seedlings growing on the sorghum roots and the length were log transformed to achieve the assumptions of ANOVA. Tukey ${ }^{\text {ee }}$ Honestly Significant Difference (HSD) test was tested to calculate the HSD and to establish the different groups. All values $\leq$ 0.05 were considered statistically significant.

\section{RESULTS AND DISCUSSION}

\section{Genetic diversity of Striga hermonthica ecotypes}

Striga seed germination frequency

Striga seeds germinated 18 hours post-introduction of the germination stimulant (GR 24). They showed a radicle protruding from the imbibed seed-coat (Figure 1). Germination frequency of the $S$. hermonthica seeds among the populations ranged from $38.2 \%$ to $42.2 \%$ (Table 4 ).

\section{Fragment analysis}

GeneMapper $^{(\mathrm{R})}$ software (V 4.0) scoring produced electropherograms showing the number of amplified fragments and their sizes (Figure 2). Downstream fragment analysis by PowerMarker software showed that the number of fragments per each primer ranged from 3 (SSR 58) to 14 (SSR 26) with an average of 7.8 fragments (Table 5). The total number of bands visualized across all the primer combinations after correcting for repeatedness was 38 out of 39 bands. Thus, $97 \%$ of polymorphic bands were observed among the $S$. hermonthica.

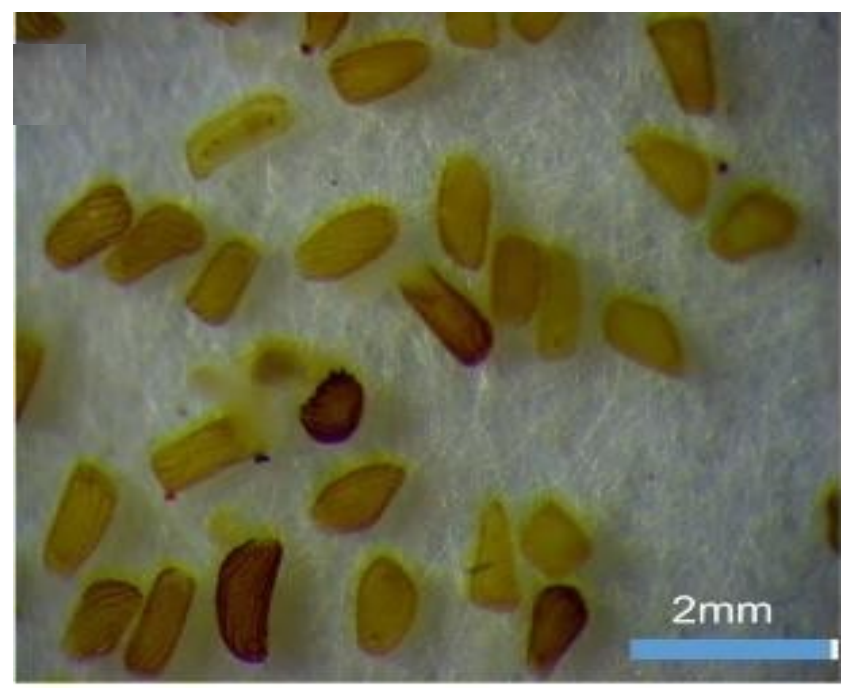

Figure 1. In vitro germinated Striga seeds 18 hours after introduction of the artificial germination stimulant (GR 24).

Table 4. Germination frequency of Striga hermonthica seeds

\begin{tabular}{llll}
\hline $\begin{array}{l}\text { Striga } \\
\text { population }\end{array}$ & No. of seeds & $\begin{array}{l}\text { Germinated } \\
\text { seeds }\end{array}$ & \% germination \\
\hline Bugiri & 200 & 81 & 40.5 \\
Ndhiwa & 180 & 76 & 42.2 \\
Iganga & 210 & 82 & 39.0 \\
Kibos & 199 & 78 & 38.2 \\
Malava & 210 & 84 & 41.0 \\
Mbale & 160 & 64 & 39.0 \\
Sio port & 300 & 120 & 40.0 \\
\hline
\end{tabular}




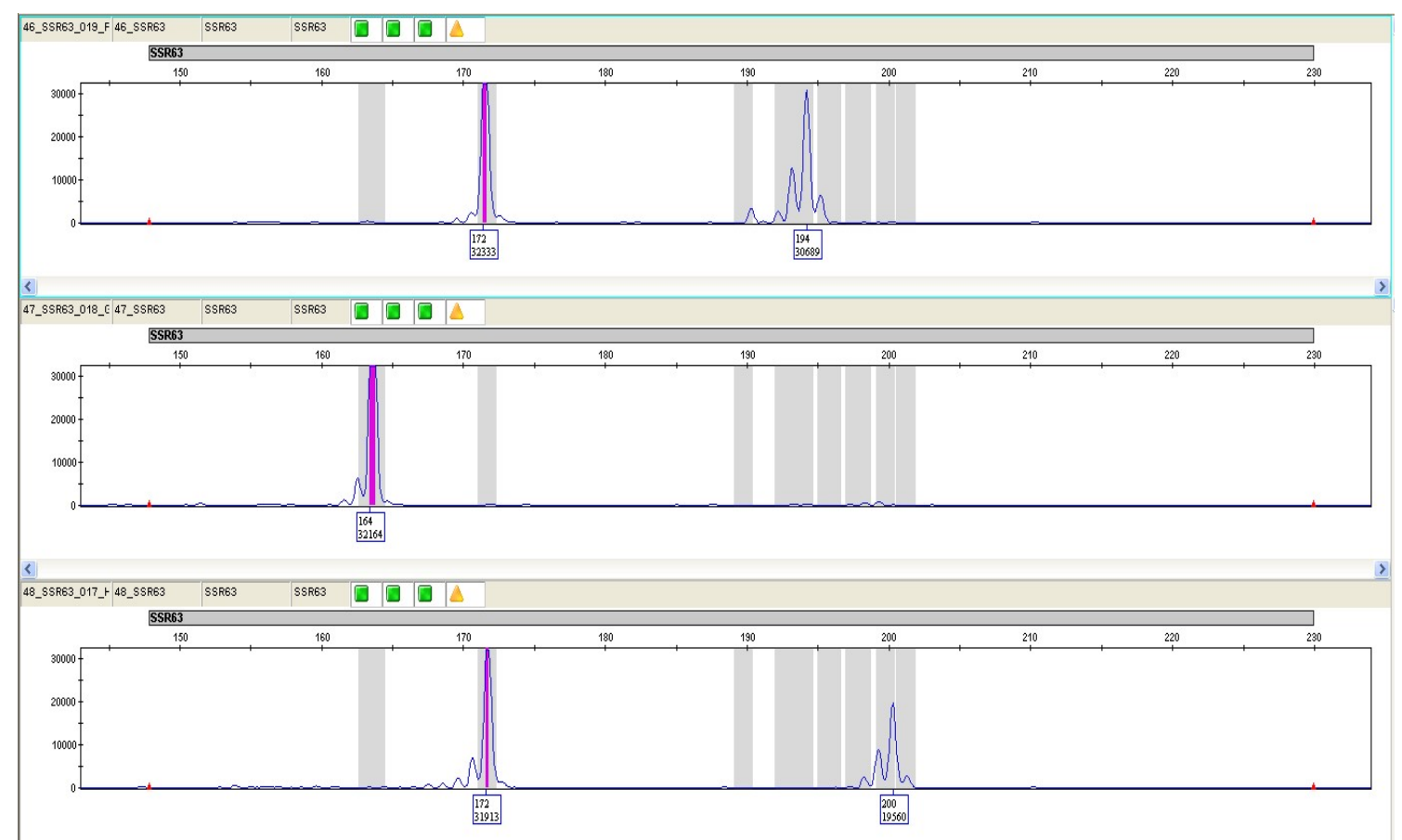

Figure 2. Representative electropherogram generated by the GeneMapper V 4.0 software for samples 17, 18, 19 using marker SSRs 63

Table 5. Summary data for each primer

\begin{tabular}{lllllll}
\hline Marker & $\begin{array}{l}\text { Major allele } \\
\text { frequency }\end{array}$ & $\begin{array}{l}\text { Allele } \\
\text { no }\end{array}$ & $\begin{array}{l}\text { Gene } \\
\text { diversity }\end{array}$ & Ho & He & PIC \\
\hline SSR26 & 0.168 & 14 & 0.899 & 0.729 & 0.817 & 0.890 \\
SSR43 & 0.629 & 7 & 0.565 & 0.416 & 0.544 & 0.532 \\
SSR53 & 0.379 & 7 & 0.752 & 0.552 & 0.544 & 0.715 \\
SSR58 & 0.665 & 3 & 0.450 & 0.571 & 0.366 & 0.354 \\
SSR63 & 0.424 & 8 & 0.757 & 0.376 & 0.652 & 0.731 \\
Mean & 0.453 & 7.8 & 0.684 & 0.529 & 0.585 & 0.645 \\
\hline
\end{tabular}

Note: Ho-observed heterozygosity, He-expected heterozygosity, PIC-polymorphic information content

The average polymorphic information content (PIC) was 0.6445 . The lowest PIC value was 0.354 for primer SSR 58. Meanwhile, the highest was 0.890 for primer SSR 26. The markers SSR 26, SSR 63 and SSR 53 gave the highest diversity values of $0.899,0.757$ and 0.752 , respectively (Table 5). Average observed heterozygosity (Ho) was 0.529 ranging from 0.376 to 0.729 while average expected heterozygosity (He) was 0.585 (Table 5 ).

Nei's genetic distance value measured the genetic relationship of seven Striga populations that ranged from 0.122 to 0.710 , in which, the smaller values indicating a closer relationship (Table 6). The highest similarity (0.122) was observed between the Bugiri and Iganga Striga populations. The lowest similarity (most diversified) was found between Striga populations Malava from Western Kenya and Mbale from Eastern Uganda revealing high genetic diversity between the two communities.
Table 6. Pairwise population matrix of Neies genetic distance (1972) for the seven Striga hermonthica populations

\begin{tabular}{lllllllll}
\hline \multicolumn{7}{c}{ Bugiri Dhiwa Iganga Kibos } & Malava Mbale Sio port \\
\hline Bugiri & 0.000 & & & & & & \\
Dhiwa & 0.219 & 0.000 & & & & & \\
Iganga & 0.122 & 0.352 & 0.000 & & & & \\
Kibos & 0.340 & 0.258 & 0.507 & 0.000 & & & \\
Malava & 0.198 & 0.209 & 0.179 & 0.444 & 0.000 & & \\
Mbale & 0.317 & 0.412 & 0.546 & 0.463 & 0.710 & 0.000 & \\
Sio port & 0.167 & 0.250 & 0.258 & .307 & 0.333 & 0.283 & 0.0000 \\
\hline
\end{tabular}

Principal component Analysis generated by GenAIEx software indicated that the first and second axis explained $28 \%$ and $14 \%$ of the observed variations, respectively (Figure 3). Still, the efficiency of the PCA was low based on the low percentage of the observed pattern on the axis. On the $1^{\text {st }}$ axis, which explains $28 \%$ of the observed pattern; Bugiri, Iganga and Sio port clustered together while on the $2^{\text {nd }}$ axis, Ndhiwa and Kibos Striga populations seem grouped. However, the PCA is not highly supported because axis 1, and 2 are explaining only $42 \%$ of the observed pattern. Meaning that the data should be interpreted with caution since the PCA is not well supported. 


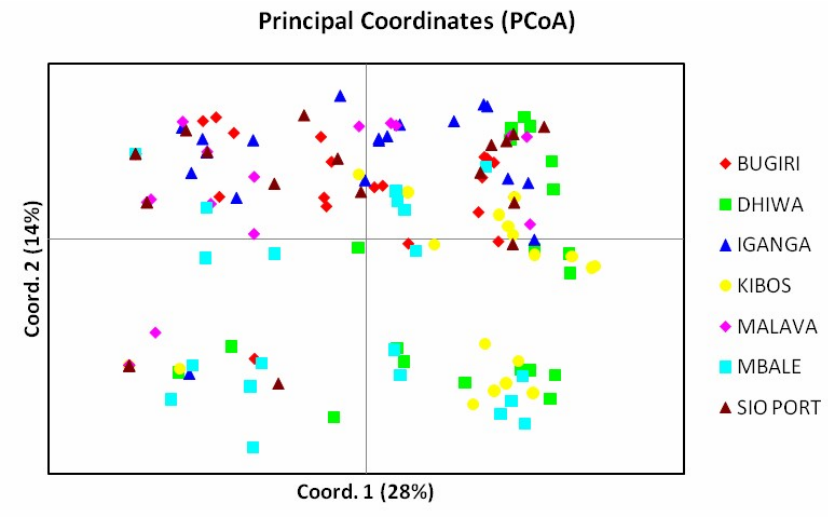

Figure 3. PCA of the genetic distance at the population level illustrating the spreading of the Striga hermonthica populations. The axes 1 and 2 clarified $42 \%$ of the variance in the distribution of the populations.

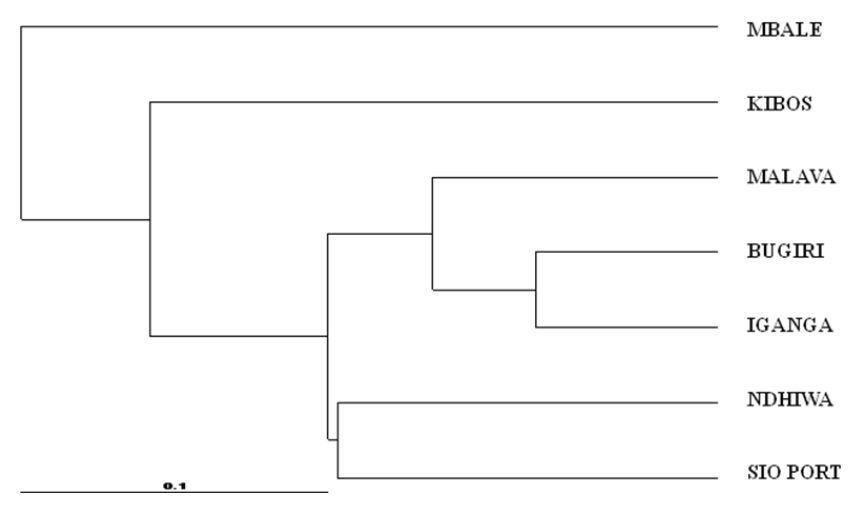

Figure 4. Phylogenetic relationship among the population of Striga hermonthica. Shown is a UPGMA dendrogram constructed based on Neiees (1972) genetic distance with PowerMarker 3.25 software.

A dendrogram constructed by the PowerMarker software using Unweighted Pair Group Method of Arithmetic Averages (UPGMA) resulted to 4 distinct clades (Figure 4) with Mbale population forming its clade $\left(4^{\text {th }}\right)$ and separating distinctively from the rest meaning that it is genetically distant from the rest. The 1 st clade is made of Sio Port and Ndhiwa (Kenyan) populations, suggesting that they are related. The $1^{\text {st }}$ clade is closely related to the $2^{\text {nd }}$ clade which is made up of Iganga and Bugiri populations that are strictly associated with Malava population from Western Kenya. Kibos population from Kenyan formed the 3rd clade which showed a distant relationship with the $1^{\text {st }}$ and $2^{\text {nd }}$ clades (Figure 4).

Analysis of Molecular Variance (GenAIEx 6.1) showed that most of the molecular variation in the S. hermonthica populations existed among individuals within populations $(87 \%)$ while the variation among populations was rather low $(13 \%)$ (Table 7$)$. Genetic differentiation among the populations was shown by the $\left(\mathrm{F}_{\mathrm{ST}}\right)$ value $=0.100$. The number of migrants $(\mathrm{Nm})$ determined the gene flow among the populations $(\mathrm{Nm}=2.239)$.
Table 7. Analysis of molecular variance for Striga hermonthica populations

\begin{tabular}{lcccccc}
\hline Source & df & SS & MS & $\begin{array}{c}\text { Est. } \\
\text { Variance }\end{array}$ & $\%$ & $\begin{array}{c}\text { P } \\
\text { values }\end{array}$ \\
\hline $\begin{array}{l}\text { Among } \\
\text { population }\end{array}$ & 6 & 121.336 & 26.223 & 0.759 & 13 & 0.001 \\
$\begin{array}{l}\text { Within } \\
\text { population }\end{array}$ & 133 & 670.400 & 5.041 & 5.800 & 87 & 0.001 \\
Total & 139 & 791.736 & & & 100 & 0.001 \\
\hline
\end{tabular}
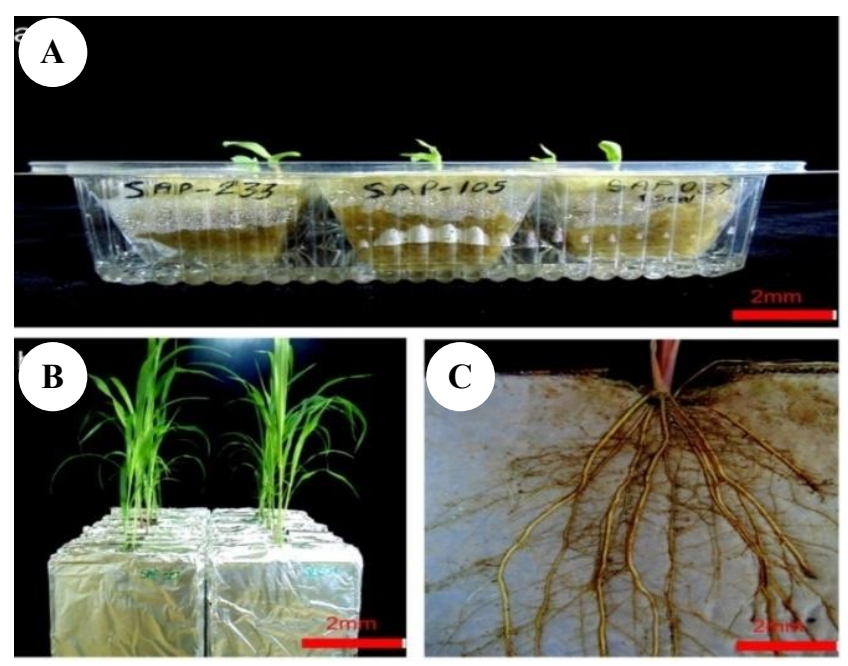

Figure 5. A. Four days old sorghum seedlings germinated on moist rockwool ready for transfer to the rhizotrons. B. Sorghum plantlets growing on the rhizotrons 10 days after transfer. C. Roots of a sorghum plant well spread on the rhizotrons and ready for infection with the Striga seeds.

\section{Assessment of sorghum for the response to Striga hermonthica infection}

Transfer of sorghum seedlings to rhizotrons

Four days old sorghum seedlings were transferred to the rhizotrons after germination of sorghum seeds (Figure 5.A). Ten days after transfer, the sorghum plants had welldeveloped root system ready for infection with the Striga seeds (Figure 5.B-C).

Striga hermonthica attachment and phenotype of resistance

Striga hermonthica adheres to the roots of the susceptible sorghum varieties by the $4^{\text {th }}$ day after inoculation. The strong attachment was characterized by swelling of the Striga radicle at the point of attachment. On the $7^{\text {th }}$ day, in resistant interactions, parasites had elicited resistance response from the host. The most visible resistance response was intense necrosis at the site of radicle attachment leading to the death of haustoria cells (Figure 6.C) and in other cases, there was successful attachment, but the haustoria failed to increase in size leading to the death of the parasite (Figure 6.D).

\section{Evaluation of susceptibility and resistance}

Twenty-one days post-infection of sorghum with the pre-germinated Striga seeds, the susceptible sorghum 
varieties had the highest number of the Striga weed-lets growing on their roots (Figure 7.A-C). The Striga weeds were growing rapidly and well developed while on the other hand; the resistant varieties supported very few Striga weeds-lets which were growing slowly and were small in size (Figure 7.D-F), an indication that they were not well supported.
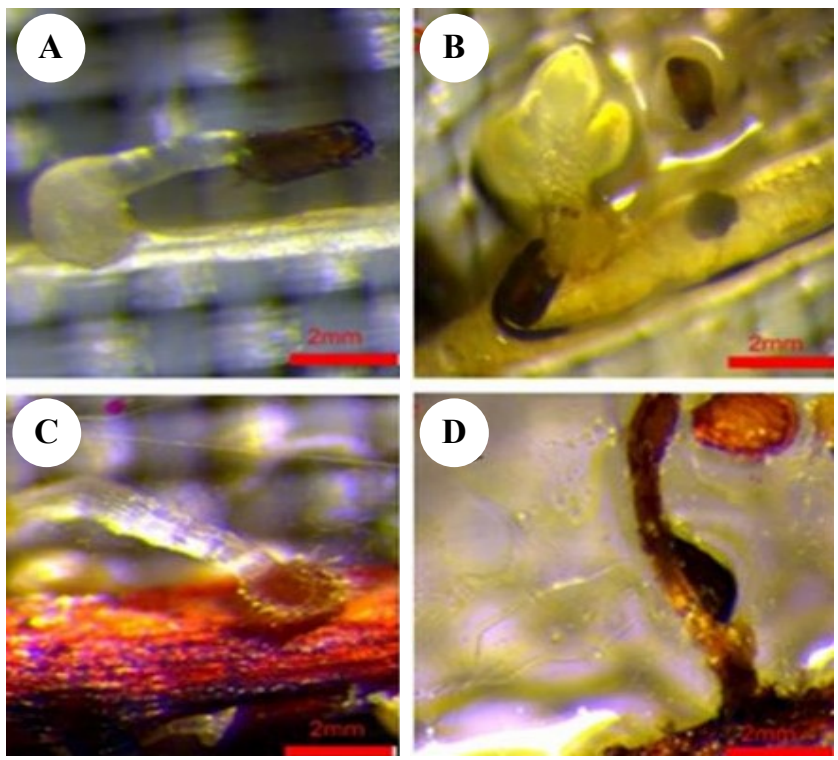

Figure 6. Sorghum varieties being infected by Striga hermonthica. A. Radicle attached to the host root and swollen into a tubercle. B. Leaf pre-mordia is emerging. C. The host root is exhibiting severe necrosis at the site of radicle attachment leading to the death of haustoria cells (darkening at the site of attachment). D. Successful attachment of $S$. hermonthica radicle but the haustoria failed to increase in size, and the parasite dies.

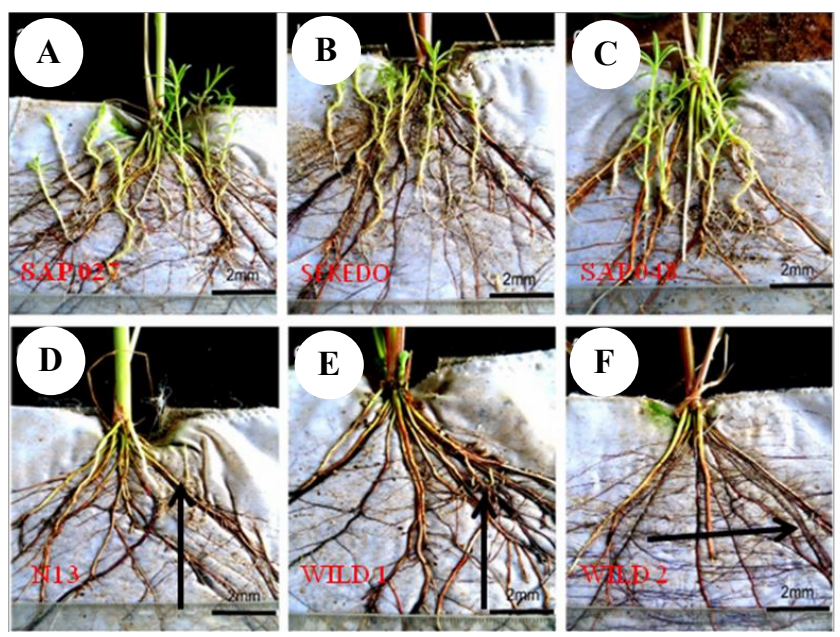

Figure 7. Striga hermonthica was growing on roots of selected Sorghum varieties in rhizotrons 21 days post-infection. A. Sap 027 , B. Sekedo, C. Sap 048 are sorghum varieties that were significantly susceptible to $S$. hermonthica with the most significant number of Striga weeds attachment on their roots. D. N13, E. Wild 1, F. Wild 2 sorghum varieties that were least susceptible to $S$. hermonthica with the smallest number of Striga weeds attached that are small in size (indicated by the arrow)
Table 8. Mean number of Striga hermonthica plants, dry biomass and length of parasites on each host plant

\begin{tabular}{llll}
\hline Variety & $\begin{array}{l}\text { No. of Striga } \\
\text { plants }\end{array}$ & $\begin{array}{l}\text { Striga dry } \\
\text { biomass }(\mathrm{g})\end{array}$ & $\begin{array}{l}\text { Striga length } \\
(\mathbf{c m})\end{array}$ \\
\hline Sap 027 & $10.667 \pm 1.201^{\mathrm{a}}$ & $0.323 \pm 0.020^{\mathrm{a}}$ & $7.967 \pm 0.033^{\mathrm{a}}$ \\
Epurpur & $8.667 \pm 1.201^{\mathrm{a}}$ & $0.200 \pm 0.012^{\mathrm{b}}$ & $7.633 \pm 0.318^{\mathrm{a}}$ \\
Sap 048 & $8.667 \pm 1.452^{\mathrm{a}}$ & $0.287 \pm 0.024^{\mathrm{a}}$ & $7.133 \pm 0.186^{\mathrm{a}}$ \\
Sap 034 & $8.333 \pm 0.881^{\mathrm{a}}$ & $0.267 \pm 0.018^{\mathrm{a}}$ & $7.167 \pm 0.376^{\mathrm{a}}$ \\
SRS 208/1 & $8.000 \pm 2.000^{\mathrm{a}}$ & $0.197 \pm 0.032^{\mathrm{b}}$ & $5.200 \pm 0.416^{\mathrm{a}}$ \\
Sekedo & $7.000 \pm 1.527^{\mathrm{a}}$ & $0.213 \pm 0.041^{\mathrm{b}}$ & $5.900 \pm 1.137^{\mathrm{a}}$ \\
Ochuti & $7.000 \pm 0.577^{\mathrm{a}}$ & $0.213 \pm 0.018^{\mathrm{b}}$ & $5.133 \pm 1.184^{\mathrm{a}}$ \\
N13 & $0.667 \pm 0.333^{\mathrm{b}}$ & $0.017 \pm 0.009^{\mathrm{c}}$ & $0.633 \pm 0.318^{\mathrm{b}}$ \\
Wild 1 & $0.667 \pm 0.333^{\mathrm{b}}$ & $0.007 \pm 0.003^{\mathrm{c}}$ & $0.267 \pm 0.145^{\mathrm{b}}$ \\
Asareca W2 & $0.667 \pm 0.333^{\mathrm{b}}$ & $0.007 \pm 0.003^{\mathrm{c}}$ & $1.100 \pm 0.666^{\mathrm{b}}$ \\
Wild 2 & $0.667 \pm 0.666^{\mathrm{b}}$ & $0.007 \pm 0.007^{\mathrm{c}}$ & $0.500 \pm 0.500^{\mathrm{b}}$ \\
Asareca AG3 & $0.333 \pm 0.333^{\mathrm{b}}$ & $0.003 \pm 0.003^{\mathrm{c}}$ & $0.967 \pm 0.967^{\mathrm{b}}$ \\
\hline N
\end{tabular}

Note: Data presented for Striga numbers, dry biomass, and length are means \pm SE. Means shown in the same column with the same letters are not significantly different according to Tukey,s HSD test $(\mathrm{P}<0.05)$

Evaluation of Striga hermonthica dry biomass, length, and number

Twenty-one days post-infection, average Striga length on each of the sorghum plant ranged from $0.267 \mathrm{~cm}$ (Wild 1) to $7.967 \mathrm{~cm}$ (Sap 027), Striga dry biomass varied from $0.003 \mathrm{~g}$ (Asareca AG3) to 0.323 (Sap 027) while Striga plant-let count on each sorghum plant ranged from 0.333 (Asareca AG3) to 10.667 (Sap 027) (Table 8).

Generally, Sap 027, Sap 034, Sap 048, Epurpur, SRS 208/1, Sekedo and Ochuti varieties promoted the highest number of the Striga plants growing on their roots; the highest Striga means dry biomass and the most upper mean length (Table 8). Conversely, Wild 1, Wild 2, N13, Asareca AG3 and Asareca W2 varieties supported very few Striga plant-lets growing on their roots which had small mean length and low dry biomass (Table 4.5). According to Tukey ${ }^{\text {ee }}$ HSD test, there was a highly significant difference in the means of some Striga, Striga dry biomass and Striga length growing on the roots of sorghum varieties between the susceptible and resistant varieties $(\mathrm{P}<0.05)$ (Table 8$)$.

\section{Discussion}

Genetic diversity of Striga hermonthica ecotypes

Analysis of molecular variance (AMOVA) indicates that differences among individuals of $S$. hermonthica within the same population contributed $87 \%(\mathrm{P}=0.001)$ of the genetic differences while $13 \%$ of the variations were attributed to differences among $S$. hermonthica populations. S. hermonthica is an obligate out-crossing species (Safa et al. 1984) and therefore it is expected to show less differentiation between populations and greater diversity within populations than as seen in related autogamous species (Hamrick 1982). Also, the low Fst value $($ Fst $=0.100)$ indicates a low level of genetic differentiation among the seven $S$. hermonthica populations, and thus the first hypothesis is accepted.

The aforementioned low levels of differentiation among the $S$. hermonthica populations perhaps due to a recent colonization effect East into Kenya and West into Uganda 
and the high level of gene flow $(\mathrm{Nm}=2.239)$ among the people. A low number of migrants per generation is considered enough gene flow to obscure or prevent the process of drift that causes populations to differentiate over time (Matt et al. 2011). This high gene flow among the $S$. hermonthica populations may have been caused by active grain trading activities in the region. Trading of cereals that are contaminated with Striga seeds frequently occurs in the study region (Berner et al. 1994). Other forms of dispersal like wind, water, and forage animals have also been shown to play a role in the dispersal of $S$. hermonthica within the region hence reducing its diversity (Matt et al. 2011). Other works have also shown high intra-population variability and no evidence of races (Olivier et al. 1998; Koyama 2000; Gethi et al. 2005). The high genetic variability within $S$. hermonthica populations presents a challenge to develop reliable Striga resistant sorghum varieties (Koyama 2000).

The dendrogram shows that Striga population from Malava (Kenya) associates with Striga from Iganga and Bugiri populations (Uganda). The two areas are however most geographically separated within the study area. Therefore, it suggests substantial gene flow between the regions. In the early 1970 s and 1980 s, there is evidence of active cereal trade between Kakamega and Ugandan people at an infamous market Chebukube. There are high chances that the cereals may have been contaminated with $S$. hermonthica seeds considering that most cereals are threshed on the ground within the contaminated field.

The EST-SSR sequences are excellent choices for genetic markers, which can be applied for molecular diagnosis and for investigating the genetic diversity as well as population structure of $S$. hermonthica (Yoshida et al. 2010). The SSR markers have been successfully employed in studying genetic diversity and phylogenetic relationships of Striga populations in Sudan (Yoshida et al. 2010) and in Mali (Matt et al. 2011) and also in leguminous plants (Sawadogo et al. 2010). In this study, 5 informative SSR primer combinations were used to analyze diversity in seven $S$. hermonthica populations collected from Kenya and Uganda. The SSR analysis is resulting in 38 unique bands ranging from 3 to 14 fragments per primer combination with a mean of 7.8 bands per primer. These values demonstrate the effectiveness of the SSR markers to elucidate diversity within the $S$. hermonthica populations. These findings are in line with work reported by Yoshida et al. (2010) where the SSR showed 27 alleles with an average of 2.7 alleles per locus. Genetic divergence analysis revealed an average gene diversity of 0.33 which is considered a moderate level of genetic diversity. Matt et al. (2011) while working on the genetic diversity of $S$. hermonthica in Mali using SSR described genetic diversity ranging from 0.687 to 0.748 whereas Yoshida et al. (2010) described genetic diversity range of 0.375 to 0.625 when working on the genetic diversity of $S$. hermonthica populations in Sudan. Using AFLP markers, Gethi et al. (2005) got shallow genetic distance values falling from 0.007 to 0.025 on the analysis of $S$. hermonthica populations from Kenya. Homogeneity among the Kenyan $S$. hermonthica populations was credited to recent colonization from the Lake Victoria and the allogamous breeding system of $S$. hermonthica. However, the small genetic diversity in the Kenyan communities (Gethi et al. 2005) may have been due to less sensitive markers used (AFLP markers) as compared to the current study.

\section{Assessment of sorghum for the response to Striga infection}

This study demonstrated that there is varied resistance response to $S$. hermonthica by the different sorghum varieties studied and therefore the second hypothesis was rejected. Some varieties showed high resistance responses while others were highly susceptible to the parasite which may be attributed to the existence of genetic variations in the different sorghum lines in response to $S$. hermonthica parasitism (Haussmann et al. 2000a). Nevertheless, complete resistance to $S$. hermonthica has not been identified in cultivated sorghum varieties (Gurney et al. 2002). All the resistant sorghum varieties tested showed some strong parasite attachment on the roots.

Among the sorghum varieties tested, there were those that were readily susceptible to $S$. hermonthica infection and others that showed resistance to the weed. The susceptible sorghum varieties had the highest number of $S$. hermonthica parasites attached on their roots, and the parasites were growing fast and healthy, suggesting that they were getting enough nutrient support from the host. On the contrary, the resistant sorghum varieties had very few $S$. hermonthica parasites growing on their roots, and the parasites comparatively had stunted growth which indicated that they could not obtain adequate nutrients from their host as is the case with those growing on the susceptible sorghum varieties. The average number, the mean length, and the dry biomass of $S$. hermonthica parasites growing on the roots of each of the sorghum variety were therefore used to group the sorghum varieties as susceptible or resistant (Berner et al. 1995). In the current study, wild-type sorghum was highly resistant to $S$. hermonthica as compared to the rest of sorghum varieties, suggests that a valuable source of resistance to sorghum may lie in the genetic potential of wild sorghum germplasm (Tanksley and McCouch 1997). Breeding for $S$. hermonthica resistance should, therefore, take advantage of the natural resistance available in the wild sorghum varieties gene pool and other sorghum cultivars showing resistance phenotype to develop elite cultivars. Mapping the resistance alleles will lead to the development of markers that can be used in the marker-assisted selection (MAS). Among the sorghum varieties tested, N13, Asareca AG3, and Asareca W2 also exhibited resistance phenotype to $S$. hermonthica. The result was not surprising since the genomic regions (QTL) associated with stable $S$. hermonthica resistance from the N13 variety were determined (AATF 2011) and selection of the QTL done and introgressed into sorghum varieties Asareca AG3 and Asareca W2 varieties at ICRISAT. The varieties N13, Asareca AG3, and Asareca W2 are known resistant genotypes with superior resistance to S. hermonthica as reported in the current study.

Wild 1, Wild 2, N13, Asareca AG3 and Asareca W2 sorghum tested in this study exhibited some resistance responses which included acute necrosis at the site of 
attachment, secure attachment but failure in growth and growth of Striga radicle away from the host root. Intense disease at the site of attachment resulted in the death of the parasites haustoria cells (marked with darkening at the tip of parasite radicle). The necrotic regions appeared at the site of parasite attachment because of localized cell death of the host tissue. Lane et al. (1993) observed acute necrosis at the site of parasite attachment to cowpea when infected with $S$. gesnorioides parasite. Scholes et al. (2011) showed similar findings in rice genotypes. The growth of Striga radicle away from the host root suggests the existence of substances that could inactivate chemical signals that attract parasite radicle to the host root (Fasil et al. 2010).

Susceptible sorghum varieties as tested in this project included; Sap 027, Sap 034, Sap 048, Epurpur, SRS 208/1, Sekedo and Ochuti. These sorghum varieties were characterized by many Striga parasites growing on their root system. The parasites were growing fast and healthy hence higher Striga mean dry biomass and mean length on each of the sorghum plants as opposed to the parasites growing on the resistant sorghum varieties, Wild 1, Wild 2, N13, Asareca AG3 and Asareca W2 varieties that had the lowest number of Striga parasites growing on their root system and the parasites had comparatively stunted growth leading to low mean Striga length and least Striga dry biomass. Similar findings have also been reported in the genetics of resistance to $S$. hermonthica in sorghum (Ahonsi et al. 2004).

The introduction and rapid diffusion of Striga resistant varieties is the most appropriate survival strategy in resource-poor, Striga prone rural economies where smallscale farmers can "et afford the other high-cost control measures against the Striga weed. However, as much as the distribution of resistant sorghum cultivars is a costeffective method of Striga management, its use per se probably have little advantages if other control strategies are not taken. Those involving the use of clean planting materials that are not contaminated with Striga, crop rotation, proper crop management practices and quarantine measures that outlaw trading in cereals that are infected with the Striga weed seeds. Integrating genetic resistance with other control measures is the smartest option possible for effective control as well as for increasing durability of resistance genes (Ejeta et al. 2007b).

In conclusion, the $S$. hermonthica populations from Western Kenya and Eastern Uganda have low genetic differentiation, and therefore the first hypothesis is accepted. The sorghum varieties Sap 027, Epurpur, Sap 048, Sap 034, SRS 208/1, Sekedo and Ochuti, are highly susceptible to Striga infection while varieties N13, Asareca W2, Asareca AG3 and the Wild-type 1 and 2 are significantly resistant to the weed and therefore the second hypothesis is rejected.

\section{REFERENCES}

AATF. 2011. Feasibility study on Striga control in sorghum. The African Technology Foundation, Nairobi, Kenya.
Ahonsi MO, Berner DK, Emechebe AM, Lagoke ST. 2004. Agric Ecosyst Environ 104: 453-463.

Atera E, Takashige I, Onyango C, Itoh K, Azuma T. 2013. Striga infestation in Kenya: status, distribution and management options. Sustain Agric Res 2: 99-108.

Atera EA, Azuma T, Ishii T. 2012a. Response of NERICA rice to Striga hermonthica infections in Western Kenya. Intl J Agric Biol 14: 271275.

Atera EA, Azuma T, Ishii T. 2012b. Farmerse perspective on the biotic constraint of Striga hermonthica and its control in Western Kenya. Weed Biol Manag 12: 53-62.

Berner D, Cardwell K, Faturoti B, Ikie F, Williams O (1994. Relative role of wind, crop seeds and cattle in dispersal of Striga spp. Plant Discovery 78: 402-406.

Berner DK, Kling JG, Singh BB (1995. Striga research and control, a perspective from Africa. Plant Dis 79: 652-660.

Doyle JJ, Doyle JL (1987. A rapid DNA isolation procedure for small quantities of fresh leaf tissue. Phytochemistry Bull 19: 11-15.

Ejeta G. 2007a. Breeding for Striga resistance in sorghum: exploitation of intricate host-parasite biology. Crop Sci 47: 216-227.

Ejeta G. 2007b. The Striga scourge in Africa: a growing pandemic. In Ejeta G, Gressel J (ed.). Integrated new technologies for Striga control: towards ending the witch-hunt. World Sci. DOI: 10.1142/9789812771506_0001.

Emechebe AM, Ellis-Jones J, Schulz S, Chikoye D, Douthwaite B, Kurea I, Tarawali G, Hussaini MA, Kormana P, Sawini A. 2004. Farmers perception of the Striga problem and its control in northern Nigeria. Exp Agric 40: 215-232.

Fasil R, Dierick A, Vekleij S. 2010. Virulence study of Striga hermonthica populations from Tigray region (North Ethiopia). World J Agric Sci 6: 676-682.

Gethi JG, Smith SE, Mitchell SE, Kresovich S. 2005. Genetic diversity of Striga hermonthica and Striga asiatica population in Kenya. Weed Res 45: 64-73.

Gressel J, Hanafi A, Head G, Marasaa W, Obilana AB, Ochanda J, Sonissi T, Tzotso G. 2004. An economic assessment of novel Striga management options in sorghum. International IPM Conference, September 2002, Kampala Uganda.

Gurney AL, Press MC, Scholes JD. 2002. Can wild relatives of sorghum provide new resources of resistance or tolerance against Striga species? Weed Res 42: 317-324.

Gurney AL, Slates J, Press MC, Scholes JD. 2006. A novel form of resistance in rice to angiosperm parasite Striga hermonthica. New Phytol 169:199-208.

Hamrick J. 1982. Plant population genetics and evolution. Amer J Bot 69 (10): 1685-1693.

Haussmann BIG, Hess DE, Welz HG, Geiger HH. 2000. Improved methodologies for breeding Striga resistant sorghums. Field Crop Res 66: 195-211.

Hewitt EJ (1966. Sand and water culture methods used in the study of plant nutrition. Exp Agric 2 (2): 547.

Jamil M, Rodenburg J, Charnikhova T, Bouwmeester HJ. 2011. Preattachment Striga hermonthica resistance of NERICA cultivars based on low strigolactone production. New Phytol 192: 964-975.

Koyama ML. 2000. Genetic variability of Striga hermonthica and effect of resistant cultivars on Striga population dynamics. In: Haussmann BIG, breeding for resistance in cereals. Margraf Verlag, Waikersheim.

Lane JA, Bailey JA, Bitler RC, Terry PJ (1993. Resistance of cowpea (Vigna unquiculata (L.) to Striga gesnerioides (Wild) Vatke, a parasitic angiosperm. New Phytol 125: 405-412.

Liu K, Muse VS. 2006. PowerMarker: an integrated analysis environment for genetic marker analysis. Bioinformatics 21 (9): 2128-2129.

Matt C, Thomas A, Van M, Peter M, Diarah G, Heino K. 2011. Genetic diversity of parasitic weed Striga hermonthica on sorghum and pearl millet in Mali. Trop Plant Biol 4: 91-98.

Matusova R, Van Mourik T, Bouwmester HJ. 2004) changes in the sensitivity of parasitic weed seeds to germination stimulants. Seed Sci Res 14: 335-344.

Mohamed KI, Bolin LJ, Musselman LJ, Peterson AT. 2003. Genetic diversity of Striga and implications for control and modeling future distributions. Integr New Technol Striga 2: 105-200

Murashige T, Skoog F (1962. A revised medium for rapid growth and bioassay with tobacco tissue cultures. Plant Physiol 15: 473-497.

Musselman LJ (1987. Taxonomy of witch-weeds. Parasit Weeds Agric 1: $3-12$. 
Nei M (1972. Genetic distance between populations. Amer Natur 106: 283-392.

Olivier A, Glassman J-C, Laud C, Salle G, Leroux GD (1998. An insight into the population structure and genetic diversity of Striga hermonthica in West Africa. Plant Syst Evol 209: 114-121.

Parker C. 2009. Observations on the current status of Orobanchaceae and Striga problem worldwide. Pest Manag Sci 65: 453-459.

Peakall R, Smouse PE. 2012. GenAIEx 6.5: genetic analysis in Excel. Population genetic software for teaching and research-an update Bioinformatics 28(19): 2537-2539.

Rasha AM, Adil A, Mohamed KI, Babiker T. 2009. Specificity and genetic relatedness among Striga hermonthica strains in Sudan. Life Sci 3: 1159-1166.

Rispail N, Dita MA, Gonzalez-Verdejo C, Perez-de-luque A, Castillejo MA, Prats E, Roman B, Jorrins J, Rubiales D. 2007. Plant resistance to parasitic plants: molecular approaches to an old foe. New Phytol 173 (4): 703-712.

Runo S, Macharia S, Alakonya A, Machuka S, Sinha N, Scholes J. 2012. Striga parasitizes transgenic hairy roots of Zea mays and provides a tool for studying plant-plant interactions. Plant Meth 8: 20. DOI: 10.1186/1746-4811-8-20.

Safa S, Jones B, Musselman (1984. Mechanism favoring out-breeding in Striga hermonthica. New Phytol 96: 229-305.
Sauerborn J, Kranz B, Mercer-Quarshie H. 2003. Organic amendments mitigate heterotrophic weed infestation in savannah agriculture. Appl Soil Ecol 23: 181-186.

Sawadogo M, Jeremy T, Gouda B, Michael P. 2010. Genetic diversity of cowpea cultivars in Burkina Faso resistant to Striga gesnerioides. African J Biotechnol 9 (48): 8146-8153.

Scholes JD, Mamadou C, Arnaud B, Jonne R, Press MC. 2011. New Rice for Africa (NERICA) cultivars exhibit different levels of postattachment resistance against the parasitic weeds S. hermonthica and S. asiatica. New Phytol 192: 952-963.

Semagn K, Bjornstad A, Ndjiondjop MN. 2006. An overview of molecular marker methods for plants. African J Biotechnol 5 (25): 2540-2568.

Tanksley SD, McCouch SR (1997. Seed banks and molecular maps: unlocking genetic potential from the wild. Science 277: 1063-1066.

Westwood JH, John I, Timko MP, Claude W. 2010. The evolution of parasitism in plants. New Trends Plant Sci 15 (4): 227-235.

Woomer PL, Savala C. 2009. Mobilizing Striga control technologies in Kenya. African Crop Sci 9: 677-681.

Yoshida S, Juliane I, Nasrein K, Ken S. 2010. A full length enriched cDNA library and expressed sequence tag analysis of the parasitic weed, Striga hermonthica. BMC Plant Biol 10: 55. DOI: 10.1186/1471-2229-10-55. 